JRPIPM, Vol. 1 (2018, no. 2, pp. 95-105)

Jurnal Riset Pendidikan dan Inovasi Pembelajaran Matematika

ISSN: 2581-0480 (electronic)

URL: https://journal.unesa.ac.id/index.php/jrpipm/

\title{
Pengaruh Model Pembelajaran Berbasis Penemuan terhadap Kemampuan Berpikir Kritis Matematis dan Self Concept dengan Mengontrol Kemampuan Awal Peserta Didik Kelas VII SMP pada Materi Bangun Datar
}

\author{
Widayati $^{1}$ \\ Pasca Sarjana Pendidikan Matematika, Universitas Negeri Jakarta \\ Widai65wy@gmail.com
}

\begin{abstract}
Abstrak
Penelitian ini bertujuan untuk mengetahui pengaruh model pembelajaran berbasis penemuan terhadap kemampuan berpikir kritis matematis dan self concept dengan mengontrol kemampuan awal peserta didik SMP pada materi bangun datar pada tahun pelajaran 2016/2017. Metode penelitian yang digunakan dalam penelitian ini adalah metode quasi eksperimen dengan rancangan Posttest Only Control Group Design. Sampel dalam penelitian ini berjumlah 96 orang peserta didik yang dipilih dengan menggunakan teknik cluster random sampling dengan tiga kelas sampel. Metode pengumpulan data dalam penelitian ini diperoleh melalui pemberian tes kemampuan awal, tes kemampuan berpikir kritis matematis, dan angket self concept yang telah divalidasi dan diuji reliabilitasnya. Data diolah menggunakan analisis kovarians (ANKOVA) dan dilanjutkan dengan Uji-t terkoreksi. Hasil penelitian yang diperoleh menunjukkan bahwa 1) Ada perbedaan pengaruh model pembelajaran berbasis penemuan terhadap kemampuan berpikir kritis matematis dan sel concept dengan mengontrol kemampuan awal peserta didik SMP kelas VII, 2) Kemampuan berpikir kritis matematis peserta didik yang belajar dengan menggunakan model pembelajaran discovery terbimbing lebih baik daripada kemampuan peserta didik yang belajar menggunakan model pembelajaran inquiry terbimbing dan model pembelajaran konvensional, (2) Self Concept matematis peserta didik yang belajar dengan menggunakan model pembelajaran discovery terbimbing lebih baik daripada kemampuan peserta didik yang belajar menggunakan model pembelajaran inquiry terbimbing dan model pembelajaran konvensional.
\end{abstract}

Kata kunci: Model Pembelajaran berbasis Penemuan, LKS, Kemampuan Berpikir kritis, dan Self concept matematis.

\section{Abstract}

This study aimed to determine the effect of discovery-based learning models on junior high school students' self-concept and mathematical critical thinking skills by controlling the initial ability on learning polygon. The research method used in this study was a quasi-experimental method with the design of Posttest Only Control Group Design. Ninety six students of grade VII selected by using cluster random sampling technique with three sample classes. The data in this study were obtained through the provision of initial ability tests, mathematical critical thinking skills tests, and self-concept questionnaires that had been validated and tested for reliability. Analysis of Covariance (ANACOVA) continued with corrected t-test were used to process the data. The results showed that 1) There were differences in the influence of discovery-based learning models on mathematical critical thinking skills and self-concept by controlling the initial ability of junior high school students of grade VII, 2) Students' critical thinking ability who learnt using guided discovery learning models are better than the ability of students who learnt using guided inquiry learning model and conventional learning models, 3) Mathematical self-concept of students who learnt by using a guided discovery learning model are better than the ability of students who learnt by using a guided inquiry learning model and conventional learning models.

Keywords: Discovery-based Learning Model, student worksheet, Critical Thinking Ability, and Mathematical Self-concept. 


\section{Pendahuluan}

Pembelajaran matematika di kelas saat ini pada umumnya berpusat pada guru dan kurang melibatkan peserta didik secara aktif. Hal ini dapat dilihat dari cara guru memberikan informasi dengan cara penulisan rumus, pemberian contoh soal yang dikerjakan bersama peserta didik kemudian diakhiri dengan pemberian soal latihan.

Pembelajaran ini masih banyak yang menekankan pemahaman peserta didik dan kurang melibatkan kemampuan berpikir tingkat tinggi seperti kemampuan berpikir kritis dan berpikir kreatif. Guru kurang memberikan kebebasan kepada peserta didik untuk mengkonstruk pendapat atau pemahamannya. Seyogyanya matematika perlu diberikan kepada semua peserta didik mulai dari sekolah dasar untuk membekali peserta didik dengan kemampuan berpikir logis, analitis, sistematis, kritis, dan kreatif, serta kemampuan bekerjasama.

Untuk mengatasi hal ini, maka pembelajaran matematika di sekolah perlu mengembangkan pendekatan dan model pembelajaran yang mendukung perkembangan kemampuan berpikir tingkat tinggi. Model-model pembelajaran yang muncul dari aktivitas matematis peserta didik kurang dapat mendorong terjadinya interaksi di kelas, sehingga pembelajaran yang mengarah kepada level berpikir matematis yang lebih tinggi tidak tercapai dan pembelajaran matematika menjadi kurang bermakna.

Menurut TIMSS 2015, peserta didik indonesia masih lemah dalam kecakapan kognitif tingkat tinggi seperti menalar, menganalisa, mengevaluasi sehingga kemampuan berpikir kritis peserta didik masih tergolong rendah; kemampuan awal dan kesiapan peserta didik indonesia untuk belajar sudah cukup baik namun masih berada di level rendah; persepsi peserta didik indonesia terhadap matematika besar, namun pada saat diminta menjawab soal-soal, kepercayaan diri terhadap kemampuan matematika yang dimilikinya masih tergolong rendah [1]. Beberapa permasalahan yang terkait dengan proses pembelajaran matematika tersebut, penulis memberikan alternatif model pembelajaran yang mempengaruhi kemampuan berpikir tingkat tinggi yaitu kemampuan berpikir kritis dan aspek afektif berupa self concept melalui model pembelajaran berbasis penemuan yang pada saat ini kurang dapat dilakukan secara maksimal dalam pembelajaran matematika.

Ennis (2011) mengemukakan bahwa berpikir kritis adalah proses berpikir refleksi yang difokuskan pada apa yang diyakini dan apa yang dilakukan [2]. Aizikovitsh dan Cheng (2015) mengungkapkan bahwa permasalahan matematika tingkat tinggi melibatkan proses berpikir analisa dan sintesa yang dapat membangkitkan peserta didik untuk berpikir kritis [3]. Peranan guru sangat diperlukan dalam proses pembelajaran di kelas, khususnya matematika sehingga kemampuan berpikir kritis peserta didik dapat dikembangkan melalui penerapan berpikir kritis ke dalam kurikulum sekolah.

Pembelajaran di sekolah saat ini dihimbau agar dapat mengembangkan kemampuan berpikir tingkat tinggi, salah satunya kemampuan berpikir kritis yang sangat diperlukan dalam menghadapi permasalahan yang berkaitan dengan kehidupan sehari-hari seiring dengan kemajuan ilmu pengetahuan dan teknologi serta masalah-masalah praktis yang sering dihadapi peserta didik. Santrock mengemukakan bahwa sejumlah karakteristik penting perkembangan self concept pada masa remaja (SMP-SMA) yaitu Abstract dan Idealistic, Gambaran tentang self concept yang abstrak, misalnya dapat dilihat dari pernyataan remaja usia 14 tahun mengenai dirinya [4]. Persepsi dan perasaan diri peserta didik menentukan hasil belajar, pengetahuan dan penilaian terhadap diri mempengaruhi cara peserta didik memahami suatu materi pelajaran yang disajikan.

Dalam pembelajaran matematika, peserta didik yang berpikir positif mengenai kemampuan matematis yang dimilikinya akan menyenangi pemecahan masalah matematika, cepat dalam pembelajaran matematika, dan mendapatkan hasil yang baik [5] Guru berperanan 
Pengaruh Model Pembelajaran Berbasis Penemuan terhadap Kemampuan Berpikir Kritis Matematis dan Self Concept dengan Mengontrol Kemampuan Awal Peserta Didik Kelas VII SMP pada Materi Bangun Datar

penting dalam hal mengembangkan self concept yang positif terhadap matematika dan memberikan pengalaman pembelajaran yang menyenangkan untuk meningkatkan self concept yang lebih tinggi dan hasil pembelajaran menjadi lebih baik.

Persepsi yang baik akan berdampak positif terhadap kemajuan belajar peserta didik, akan tetapi persepsi yang kurang baik dapat menghambat proses pembelajaran yang dilakukan, dalam hal ini peserta didik diharapkan dapat membentuk persepsi dan perasaan yang positif dengan cara mengevaluasi segala kekurangannya dan berusaha untuk mengurangi persepsipersepsi dan perasaan negatif terhadap diri sendiri. Berdasarkan hal yang dikemukakan di atas, maka dapat disimpulkan bahwa self concept adalah persepsi seseorang terhadap dirinya, lingkungan, dan kemampuan-kemampuan yang dimilikinya.

Model pembelajaran inovatif mulai berkembang seiring kemajuan ilmu dan teknologi, salah satu diantaranya adalah model pembelajaran berbasis penemuan. Inquiry terbimbing dan discovery terbimbing merupakan model-model pembelajaran yang diterapkan pada pelaksanaan kurikulum 2013 edisi 2016 khususnya kelas VII SMP. Keduanya dapat diterapkan kepada peserta didik SMP, hal ini dikarenakan peserta didik SMP masih memerlukan bantuan guru dalam proses pembelajaran.

Inquiry terbimbing merupakan proses menemukan jawaban pertanyaan dan menyelesaikan masalah berdasarkan fakta dan pengamatan, sedangkan discovery terbimbing adalah proses menemukan konsep melalui serangkaian data atau informasi yang diperoleh melalui pengamatan atau percobaan [6-9]. Penelitian yang dilakukan oleh Hermawan dan Sondang (2013) serta Yama dkk (2015). Keduanya hanya terbatas mendeskripsikan perbedaan hasil belajar peserta didik setelah diberikan perlakuan model-model pembelajaran berbasis penemuan dan model pembelajaran konvensional [6,7]. Penelitian mengenai peningkatan kemampuan berpikir kritis dan self concept telah dilakukan oleh Susilawati dan Hidayat (2016) dengan menggunakan model pembelajaran saintifik, alternatif model pembelajaran yang akan dilakukan dalam penelitian ini adalah model pembelajaran berbasis penemuan [10].

Penelitian yang akan dilakukan tidak hanya pada perbedaan hasil belajar peserta didik tetapi melihat pengaruhnya terhadap kemampuan kognitif yaitu kemampuan berpikir kritis matematis dan kemampuan afektif yaitu self concept peserta didik.

Penerapan model pembelajaran tidak terlepas dari kesiapan peserta didik untuk menerima pembelajaran, salah satu diantaranya adalah kemampuan awal peserta didik sebelum menerima konsep yang akan diajarkan. Kemampuan awal ini dapat berupa penguasaan materi prasyarat yang dibutuhkan sebelum mempelajari materi selanjutnya, sehingga memudahkan peserta didik untuk memahami materi yang akan diberikan. Pengaruh model pembelajaran yang diterapkan terhadap hasil belajar peserta didik akan terlihat setelah mengurangi pengaruh linear (mengontrol) kemampuan awal peserta didik.

Dari fenomena yang terjadi di kelas, hasil TIMSS 2015, dan beberapa penelitian yang telah dikemukakan di atas, terkait dengan pembelajaran pada kurikulum 2013 yang pada hakekatnya menuntut peserta didik untuk aktif, sehingga guru berusaha untuk mencari alternatif model pembelajaran yang tepat untuk digunakan dalam proses pembelajaran.

Model pembelajaran berbasis penemuan merupakan salah satu model pembelajaran yang berpusat pada peserta didik, maka akan dilakukan penelitian mengenai alternatif proses pembelajaran matematika untuk memperoleh gambaran yang obyektif tentang pengaruh model pembelajaran berbasis penemuan yaitu model pembelajaran inquiry terbimbing dan discovery terbimbing terhadap kemampuan berpikir kritis matematis (aspek kognitif) dan self concept (aspek afektif) dengan mengontrol kemampuan awal peserta didik SMP kelas VII pada materi bangun datar.

Perbedaan yang cukup mendasar dari kedua model pembelajaran tersebut adalah terletak pada hasil akhirnya, inquiry terbimbing tidak dapat diprediksi hasil akhirnya karena semuanya bergantung kepada hasil penemuan peserta didik, peran guru dalam proses pembelajaran 
mengarahkan kepada tujuan yang akan dicapai sedangkan discovery terbimbing, hasil yang akan diperoleh peserta didik sudah jelas karena petunjuknya ada dan tujuan diadakan penemuan ini guru yang menentukan, sehingga seolah-olah masalah yang disajikan merupakan rekayasa dari guru.

Model konvensional merupakan salah satu dari model-model pembelajaran yang dimana cara penyampaiannya secara lisan atau penjelasan langsung kepada sekelompok peserta didik. Gerlach dan Ely (1980) mengemukakan bahwa model pembelajaran konvensional lazim dipergunakan dalam pembelajaran tradisional, biasanya lebih bersifat komunikasi satu arah dan pengajar lebih besar peranannya [11].

Dari pendapat-pendapat tersebut, maka dapat disimpulkan bahwa kemampuan awal adalah kemampuan yang diharapkan dapat dikuasai oleh peserta didik sebelum mempelajari konsep baru yang berkaitan dengan konsep sebelumnya. Kemampuan awal yang dimiliki peserta didik sesuai dengan pengetahuan yang akan diberikan dikuasai dengan baik dan mendalam sehingga peserta didik tidak mengalami kesulitan ketika mempelajari materi pelajaran selanjutnya.

Dari paparan di atas, maka penulis mengadakan penelitian mengenai "Pengaruh Model Pembelajaran Berbasis Penemuan terhadap kemampuan Berpikir Matematis dan Self Concept dengan mengontrol Kemampuan Awal Peserta Didik".

\section{Metode}

Metode yang digunakan dalam penelitian ini adalah metode quasi eksperimen. Penelitian ini dilaksanakan di Sekolah Menengah Pertama Negeri (SMPN) 89 Jakarta dan dilaksanakan pada semester genap tahun pembelajaran 2016 - 2017. Desain penelitian ini menggunakan desain penelitian berbentuk Nonequivalent Posttest-Only Control Group Design.

Pengumpulan data menggunakan tes tertulis dalam bentuk tes uraian sebagai Instrumen kemampuan berpikir kritis matematis, angket skala sikap self concept dengan skala Likert sebagai instrumen self concept dan soal pilihan ganda sebagai instrumen kemampuan awal.

Dalam penelitian ini digunakan tiga teknik analisis yaitu analisis deskriptif, analisis uji persyaratan, analisis kovarians (ANKOVA) satu jalur dengan design eksperimen factorial $3 \mathrm{x}$ 1 treatment by level.

\section{Hasil Penelitian}

Pengujian hipotesis menggunakan ANKOVA diperoleh taraf signifikans $\mathrm{A}=0,009<$ 0,05 dan Fo $(\mathrm{A})=7,159>\mathrm{F}_{\mathrm{tab}}=3,06$, maka hal ini berarti terdapat perbedaan kemampuan berpikir kritis matematis antara peserta didik yang belajar dengan model pembelajaran inquiry terbimbing, discovery terbimbing, dan konvensional dengan mengontrol kemampuan awal. Pada Corrected Model, diperoleh taraf signifikans $\mathrm{M}=0,029<0,05 \mathrm{Fo}=5,920>\mathrm{F}_{\mathrm{tab}}=3,09$. Maka hal ini berarti bahwa kovariat kemampuan Awal (A) dan model pembelajaran (M) secara simultan berpengaruh terhadap kemampuan berpikir kritis matematis. Hal ini dapat dilihat pada tabel berikut :

TABEL 1. Statistik Uji-F untuk Faktor Model Pembelajaran terhadap Kemampuan Berpikir Kritis Matematis Peserta didik dengan mengontrol Kemampuan awal peserta didik.

\begin{tabular}{|c|c|c|c|c|c|c|}
\hline $\begin{array}{l}\text { Sumber } \\
\text { Varians }\end{array}$ & JK & Df & RJK & F & Sig. & $F_{\text {tabel }}$ \\
\hline $\begin{array}{l}\text { Corrected } \\
\text { Model }\end{array}$ & $972,718^{a}$ & 3 & 324,239 & 5,920 & ,001 & \\
\hline Intercept & 4047,281 & 1 & 4047,281 & 73,892 & ,000 & \\
\hline $\mathrm{M}$ & 404,831 & 2 & 202,416 & 3,696 & ,029 & \\
\hline
\end{tabular}


Pengaruh Model Pembelajaran Berbasis Penemuan terhadap Kemampuan Berpikir Kritis Matematis dan Self Concept dengan Mengontrol Kemampuan Awal Peserta Didik Kelas VII SMP pada Materi Bangun Datar

\begin{tabular}{|l|r|r|r|r|r|r|}
\hline A & 392,135 & 1 & 392,135 & 7,159 &, 009 & \multirow{2}{*}{3,09} \\
\cline { 1 - 5 } Error & 5039,115 & 92 & 54,773 & & \\
\cline { 1 - 5 } Total & 118900,000 & 96 & & & \\
\cline { 1 - 4 } $\begin{array}{l}\text { Corrected } \\
\text { Total }\end{array}$ & 6011,833 & 95 & & & \\
\hline
\end{tabular}

Hasil perhitungan menentukan rata-rata kemampuan awal dan kemampuan berpikir kritis matematis masing-masing kelompok pembelajaran sebagai berikut :

TABEL 2. Rata-rata kemampuan awal dan rata-rata kemampuan berpikir kritis matematis pada masing-masing kelompok pembelajaran.

\begin{tabular}{|c|c|c|c|c|}
\hline Statistik & MI & MD & MK & Jumlah \\
\hline $\mathrm{N}$ & 32 & 32 & 32 & 96 \\
\hline rata2 kemampuan awal & 9,97 & 9,22 & 8,75 & 27,94 \\
\hline rata2 berpikir kritis matematis & 36,56 & 35,44 & 30,88 & 102,88 \\
\hline
\end{tabular}

Dari perhitungan rata-rata tersebut maka diperhitungkan rata-rata terkoreksi kemampuan berpikir kritis matematis dari masing-masing kelompok pembelajaran dengan cara mengontrol kemampuan awal.

Rata-rata nilai residu adalah selisih antara rata - rata nilai dan koefisien regresi Kemampuan Berpikir Kritis Matematis atas Kemampuan Awal di dalam kelompok Rata-rata terkoreksi Kemampuan Berpikir Kritis Matematis $=$

$$
\overline{\mathbf{B}}-\overline{\mathbf{b}}\left(\overline{\mathbf{A}}-\sum \overline{\mathbf{A}}\right)
$$

Keterangan :

$\overline{\mathrm{B}}=$ Rata-rata kemampuan berpikir kritis matematis suatu kelompok pembelajaran

$\overline{\mathrm{b}}=$ Koefisien kemampuan berpikir kritis matematis atas kemampuan awal di dalam kelompok

$\overline{\mathrm{A}}=$ Rata-rata Kemampuan Awal suatu kelompok

$\sum \overline{\mathrm{A}}=$ Jumlah rata-rata kemampuan awal semua kelompok.

Rata-rata terkoreksi kemampuan berpikir kritis matematis masing-masing kelompok pembelajaran dapat diperhatikan pada tabel berikut :

TABEL 3. Rerata Terkoreksi Kemampuan Berpikir Kritis Matematis pada Setiap Kelompok yang dibentuk oleh Faktor Model Pembelajaran

\begin{tabular}{|c|c|c|}
\hline \multicolumn{3}{|c|}{ Model Pembelajaran (M) } \\
\hline $\begin{array}{c}\text { Inquiry Terbimbing } \\
\left(\mathbf{M}_{\mathbf{I}}\right)\end{array}$ & $\begin{array}{c}\text { Discovery Terbimbing } \\
\left(\mathbf{M}_{\mathbf{D}}\right)\end{array}$ & Konvensional $\left(\mathbf{M}_{\mathbf{K}}\right)$ \\
\hline 51,890 & 51,405 & 47,242 \\
\hline
\end{tabular}

TABEL 4. Hasil Uji t- Ankova (uji-t dikoreksi) dengan spss-20 untuk mengetahui perbedaan nilai-nilai residu kemampuan berpikir kritis matematis peserta didik yang belajar menggunakan model pembelajaran dengan mengontrol Kemampuan awal peserta didik.

\begin{tabular}{|c|c|c|c|c|c|c|}
\hline \multirow{2}{*}{ Parameter } & \multirow{2}{*}{ B } & \multirow{2}{*}{ Std. Error } & \multirow{2}{*}{$\mathbf{T}$} & \multirow{2}{*}{ Sig. } & \multicolumn{2}{|c|}{ 95\% Confidence Interval } \\
\hline & & & & & Lower Bound & Upper Bound \\
\hline Intercept & 23,408 & 3,082 & 7,594 &, 000 & 17,286 & 29,529 \\
\hline$[\mathrm{M}=1]$ & 4,647 & 1,891 & 2,458 &, 016 &, 893 & 8,402 \\
\hline$[\mathrm{M}=2]$ & 4,162 & 1,856 & 2,242 &, 027 & ,476 & 7,849 \\
\hline$[\mathrm{M}=3]$ & $0^{\mathrm{a}}$ & & & & & \\
\hline A & ,853 & ,319 & 2,676 &, 009 & 220 & 1,487 \\
\hline
\end{tabular}


Keterangan :

$\mathrm{M}=1$ : Model Pembelajaran Inquiry Terbimbing

$\mathrm{M}=2$ : Model Pembelajaran Discovery Terbimbing

$\mathrm{M}=3$ : Model Pembelajaran Konvensional

Dari tabel di atas menunjukkan bahwa nilai signifikans hasil kemampuan berpikir kritis matematis kelompok pembelajaran inquiry terbimbing dan kelompok pembelajaran discovery terbimbing lebih dari 0,05 . Ini berarti ada perbedaan nilai-nilai residu kemampuan berpikir kritis matematis peserta didik yang belajar menggunakan masing-masing model pembelajaran dengan mengontrol kemampuan awal peserta didik SMP pada materi bangun datar. berikut :

Kesimpulan yang dapat diambil dari pengujian hipotesis yang dilakukan adalah sebagai

TABEL 5. Hasil Uji Hipotesis Lanjut Kemampuan Berpikir Kritis Matematis dengan Statistik Uji-t-ANKOVA terkoreksi

\begin{tabular}{|c|c|c|c|l|}
\hline $\begin{array}{c}\text { Nilai } \\
\text { Kontras }\end{array}$ & (Se) & thitung & tabel & \multicolumn{1}{c|}{ Kesimpulan } \\
\hline 4,65 & 1,891 & 2,458 & 1,69 & $\begin{array}{l}\text { Rata-rata terkoreksi kemampuan berpikir kritis matematis peserta didik } \\
\text { yang belajar menggunakan model pembelajaran inquiry terbimbing } \\
\text { lebih tinggi daripada peserta didik yang belajar menggunakan model } \\
\text { pembelajaran konvensional dengan mengontrol kemampuan awal } \\
\text { peserta didik. }\end{array}$ \\
\hline 4,163 & 1,856 & 2,242 & 1,69 & $\begin{array}{l}\text { Rata-rata terkoreksi kemampuan berpikir kritis matematis peserta didik } \\
\text { yang belajar menggunakan model pembelajaran discovery terbimbing } \\
\text { lebih tinggi daripada peserta didik yang belajar menggunakan model } \\
\text { pembelajaran konvensional dengan mengontrol kemampuan awal } \\
\text { peserta didik. }\end{array}$ \\
\hline 0,485 & 1,866 & 0.260 & 1,69 & $\begin{array}{l}\text { Rata-rata terkoreksi kemampuan berpikir kritis matematis peserta didik } \\
\text { yang belajar menggunakan model pembelajaran inquiry terbimbing } \\
\text { lebih rendah daripada peserta didik yang belajar menggunakan model } \\
\text { pembelajaran discovery terbimbing dengan mengontrol kemampuan } \\
\text { awal peserta didik. }\end{array}$ \\
\hline
\end{tabular}

Pengujian hipotesis menggunakan ANKOVA diperoleh taraf signifikan $\mathrm{A}=0,000<0,05$ dan $\mathrm{Fo}(\mathrm{A})=115,109>\mathrm{F}_{\mathrm{tab}}=3,94$, maka hal ini berarti bahwa maka hal ini berarti terdapat perbedaan self concept matematis antara peserta didik yang belajar dengan model pembelajaran inquiry terbimbing, discovery terbimbing, dan konvensional dengan mengontrol kemampuan awal.

Pada Corrected Model, diperoleh $F_{0}=45,446>F_{t a b}=3,94$. Maka hal ini berarti bahwa kovariat kemampuan Awal (A) dan model pembelajaran (M) secara simultan berpengaruh terhadap self concept matematis (S).

TABEL 6. Statistik Uji-F untuk Faktor Model Pembelajaran terhadap Self Concept Matematis Peserta didik dengan mengontrol Kemampuan awal peserta didik.

\begin{tabular}{|c|c|c|c|c|c|c|}
\hline $\begin{array}{l}\text { Sumber } \\
\text { Varians }\end{array}$ & JK & Df & RJK & $\mathbf{F}$ & Sig. & $F_{\text {tabel }}$ \\
\hline $\begin{array}{l}\text { Corrected } \\
\text { Model }\end{array}$ & $658,790^{\mathrm{a}}$ & 3 & 219,597 & 45,446 &, 000 & \multirow[t]{6}{*}{3,94} \\
\hline Intercept & 3005,417 & 1 & 3005,417 & 621,983 &, 000 & \\
\hline $\mathrm{S}$ & 33,775 & 2 & 16,888 & 3,495 &, 034 & \\
\hline A & 556,207 & 1 & 556,207 & 115,109 &, 000 & \\
\hline Error & 444,543 & 92 & 4,832 & & & \\
\hline Total & 100434,000 & 96 & & & & \\
\hline
\end{tabular}


Pengaruh Model Pembelajaran Berbasis Penemuan terhadap Kemampuan Berpikir Kritis Matematis dan Self Concept dengan Mengontrol Kemampuan Awal Peserta Didik Kelas VII SMP pada Materi Bangun Datar

\begin{tabular}{|l|l|r|l|l|l|l|}
\hline $\begin{array}{l}\text { Sumber } \\
\text { Varians }\end{array}$ & JK & Df & RJK & F & Sig. & F tabel \\
\hline $\begin{array}{l}\text { Corrected } \\
\text { Total }\end{array}$ & 1103,333 & 95 & & & & \\
\hline
\end{tabular}

Hasil perhitungan menentukan rata-rata kemampuan awal dan self concept matematis masingmasing kelompok pembelajaran sebagai berikut :

TABEL 7. Rata-rata kemampuan awal dan rata-rata self concept matematis pada masing-masing kelompok pembelajaran.

\begin{tabular}{|c|c|c|c|c|}
\hline Statistik & MI & MD & MK & Jumlah \\
\hline $\mathrm{N}$ & 32 & 32 & 32 & 96 \\
\hline rata2 kemampuan awal & 9,97 & 9,22 & 8,75 & 27,94 \\
\hline rata2 self concept matematis & 33,19 & 32,56 & 30,75 & 96,5 \\
\hline
\end{tabular}

Dari perhitungan rata-rata tersebut maka diperhitungkan rata-rata terkoreksi self concept matematis dari masing-masing kelompok pembelajaran dengan cara mengontrol kemampuan awal sebagai berikut :

Rata-rata nilai residu adalah selisih antara rata - rata nilai dan koefisien regresi Self Concept Matematis atas Kemampuan Awal di dalam kelompok. Rata-rata terkoreksi Self Concept Matematis $=\overline{\mathrm{S}}-\overline{\mathrm{S}}\left(\overline{\mathrm{A}}-\sum \overline{\mathrm{A}}\right)$

Keterangan :

$\overline{\mathrm{S}}=$ Rata-rata self concept matematis suatu kelompok pembelajaran

$\overline{\mathrm{s}}=$ koefisien self concept matematis atas kemampuan awal di dalam kelompok

$\overline{\mathrm{A}}=$ Rata-rata Kemampuan Awal suatu kelompok

$\sum \overline{\mathrm{A}}=$ Jumlah rata-rata kemampuan awal semua kelompok.

Rata-rata terkoreksi self concept matematis masing-masing kelompok pembelajaran dapat diperhatikan pada tabel berikut:

TABEL 8. Rerata Terkoreksi Self Concept Matematis pada Setiap Kelompok yang dibentuk oleh Faktor Model Pembelajaran

\begin{tabular}{|c|c|c|}
\hline \multicolumn{3}{|c|}{ Pembelajaran } \\
\hline \multicolumn{3}{|c|}{ Model Pembelajaran } \\
\hline Inquiry Terbimbing & $\begin{array}{c}\text { Discovery Terbimbing } \\
\left(\mathbf{M}_{\mathbf{I}}\right)\end{array}$ & $\begin{array}{c}\text { Konvensional } \\
\left(\mathbf{M}_{\mathbf{L}}\right)\end{array}$ \\
\hline 51,444 & 51,581 & 50,245 \\
\hline
\end{tabular}

TABEL 9. Hasil Uji t- Ankova (uji-t dikoreksi) dengan spss 20 untuk mengetahui perbedaan nilai-nilai residu self concept matematis peserta didik yang belajar menggunakan model pembelajaran dengan mengontrol Kemampuan awal peserta didik.

\begin{tabular}{|c|c|c|c|c|c|c|}
\hline \multirow{2}{*}{ Parameter } & \multirow{2}{*}{ B } & \multirow{2}{*}{ Std. Error } & \multirow{2}{*}{$\mathbf{T}$} & \multirow{2}{*}{ Sig. } & \multicolumn{2}{|c|}{ 95\% Confidence Interval } \\
\hline & & & & & Lower Bound & Upper Bound \\
\hline Intercept & 21,857 & 915 & 23,875 &, 000 & 20,039 & 23,675 \\
\hline$[\mathrm{M}=1]$ & 1,199 & ,562 & 2,135 & 035 & ,084 & 2,314 \\
\hline$[\mathrm{M}=2]$ & 1,336 & ,551 & 2,423 & ,017 & 241 & 2,431 \\
\hline$[\mathrm{M}=3]$ & $0^{\mathrm{a}}$ & & & & & \\
\hline A & 1,016 & ,095 & 10,729 & 000 & 828 & 1,205 \\
\hline
\end{tabular}

Dari tabel di atas menunjukkan bahwa nilai signifikans self concept matematis antara kelompok pembelajaran inquiry terbimbing dan konvensional lebih dari 0,05 begitu juga halnya dengan kelompok pembelajaran discovery terbimbing dan konvensional. 
Kesimpulan yang dapat diambil dari pengujian hipotesis yang dilakukan adalah sebagai berikut :

TABEL 10. Uji Hipotesis Lanjut Self Concept Matematis dengan Statistik Uji-t-ANKOVA terkoreksi

\begin{tabular}{|l|c|l|l|l|}
\hline $\begin{array}{c}\text { Nilai } \\
\text { Kontras }\end{array}$ & $\mathbf{( S e )}$ & $\mathbf{t}_{\text {hitung }}$ & $\mathbf{t}_{\text {tabel }}$ & \multicolumn{1}{c|}{ Kesimpulan } \\
\hline 1,199 & 0,562 & 2,135 & 1,69 & $\begin{array}{l}\text { Rata-rata terkoreksi Self Concept matematis peserta didik yang belajar } \\
\text { menggunakan model pembelajaran discovery terbimbing lebih tinggi } \\
\text { daripada peserta didik yang belajar menggunakan model pembelajaran } \\
\text { inquiry terbimbing dengan mengontrol kemampuan awal peserta didik. }\end{array}$ \\
\hline 1,339 & 0,551 & 2,423 & 1,69 & $\begin{array}{l}\text { Rata-rata terkoreksi Self Concept matematis peserta didik yang belajar } \\
\text { menggunakan model pembelajaran discovery terbimbing lebih tinggi } \\
\text { daripada peserta didik yang belajar menggunakan model pembelajaran } \\
\text { inquiry terbimbing dengan mengontrol kemampuan awal peserta didik. }\end{array}$ \\
\hline 0,137 & 0,554 & 0,247 & 1,69 & $\begin{array}{l}\text { Rata-rata terkoreksi Self Concept matematis peserta didik yang belajar } \\
\text { menggunakan model pembelajaran inquiry terbimbing lebih rendah } \\
\text { daripada peserta didik yang belajar menggunakan model pembelajaran } \\
\text { discovery terbimbing dengan mengontrol kemampuan awal peserta } \\
\text { didik. }\end{array}$ \\
\hline
\end{tabular}

\section{Pembahasan}

Pembelajaran inquiry terbimbing dan discovery terbimbing ini pada dasarnya berbasis penemuan, keduanya bertujuan agar peserta didik berusaha menemukan konsep pembelajaran dengan cara berdiskusi dan mendapat bimbingan guru, sehingga guru berusaha menyediakan lembar aktivitas peserta didik sebagai arahan mereka untuk memahami konsep yang diberikan. Proses pelaksanaan kedua pembelajaran ini tentunya mengalami kendala yang cukup banyak karena keterbatasan pengetahuan peserta didik untuk memahami materi yang disajikan sehingga mereka cenderung lebih banyak bertanya ketika ada yang tidak mereka pahami. Proses pembelajaran dengan menggunakan model inquiry terbimbing memerlukan kemampuan berpikir kritis matematis yang cukup baik untuk mengeksplor kemampuan yang dimilikinya untuk menguasai konsep yang diajarkan.

Berdasarkan pengamatan yang dilakukan, memang agak sulit membedakan antara kedua pembelajaran ini, karena keduanya berbasis penemuan. Perbedaannya terlihat pada penyajian materi, respon peserta didik ketika menerima pembelajaran, dan hasil pembelajaran yang diperoleh. Pada proses pembelajaran inquiry terbimbing, peserta didik berusaha keras untuk memahami konsep yang diberikan dengan mengeksplor kemampuannya sendiri, dalam hal ini guru berperanan mengarahkan pemikiran peserta didik ke arah pemahaman terhadap materi yang disajikan sedangkan pada pembelajaran discovery terbimbing, peserta didik terlihat lebih antusias karena sebelumnya konsep tersebut telah diberikan sebelumnya oleh guru tidak dalam bentuk final sehingga peserta didik berusaha memahami konsep lebih terarah.

Kenyataan di lapangan, kemampuan berpikir kritis peserta didik SMP khususnya kelas VII kurang dapat berkembang dengan baik tanpa diiringi bimbingan dari guru dan memerlukan waktu yang cukup lama sehingga kemampuan berpikir kritis matematis kelompok pembelajaran inquiry terbimbing lebih rendah daripada kelompok pembelajaran discovery terbimbing. Hal ini tidak sesuai dengan asumsi ketiga yang diajukan, mengingat proses berpikir tingkat tinggi khususnya kemampuan berpikir kritis matematis peserta didik SMP khususnya kelas VII masih memerlukan bimbingan yang lebih banyak sehingga konsep pembelajaran yang diberikan diisajikan dalam bentuk tidak final sehingga mereka berusaha mencari penyelesaiannya dengan alur-alur yang telah diberikan sebelumnya.

Karakteristik peserta didik mempengaruhi proses pembelajaran, seperti intelegensi, sikap, tingkat kedewasaan, motivasi, kemampuan awal yang dimiliki sebelumnya dan lain sebagainya. 
Pengaruh Model Pembelajaran Berbasis Penemuan terhadap Kemampuan Berpikir Kritis Matematis dan Self Concept dengan Mengontrol Kemampuan Awal Peserta Didik Kelas VII SMP pada Materi Bangun Datar

Faktor-faktor tersebut mempengaruhi hasil penelitian walaupun dalam jumlah kecil sehingga tahapan-tahapan pembelajaran masing-msing model pembelajaran yang dilakukan menjadi terhambat dan hasil pembelajaran yang diperoleh kurang baik karena keterbatasan pengetahuan peserta didik SMP khususnya kelas VII yang masih perlu banyak bimbingan dari guru.

Selain itu dapat dilihat dari hasil angket self concept matematis peserta didik pada kelas inquiry menunjukkan sikap peserta didik lebih percaya dengan kemampuan yang dimilikinya dan tingkat berpikirnya yang lebih baik daripada kelas konvensional. Mereka cenderung memiliki rasa ingin tau yang cukup besar ketika diberikan permasalahan matematika yang baru dan merasa dirinya sanggup melakukan penyelesaian matematika lebih cepat karena konsep pembelajaran yang mereka pelajari berdasarkan hasil temuan mereka dengan cara mengeksplor kemampuan matematika dengan bantuan lembar aktivitas, sehingga mereka terbiasa mencoba menyelesaikan permasalahan matematika dengan cara berdiskusi dengan teman kelompoknya.

Peserta didik yang belajar dengan model pembelajaran konvensional cenderung memandang dirinya tidak mampu menyelesaikan masalah matematika yang disajikan, sehingga mereka kurang aktif dalam pembelajaran sehingga mereka mempunyai pemikiran bahwa matematika adalah pelajaran yang sulit dan merasa tidak tertarik dengan matematika. Ketika diberikan soal yang tingkatan yang lebih tinggi mereka kerap kali enggan untuk mengerjakan sendiri, sehingga guru berusaha mengajarkan kembali. Mereka akan mengerjakan soal yang hampir sama dengan contoh soal yang sebelumnya telah dipaparkan oleh guru, sedangkan guru hanya mengganti angkanya saja dan langkah penyelesaiannya mereka ikuti.

Kajian teori yang mendukung hasil peneitian adalah faktor-faktor yang mempengaruhi self concept matematis peserta didik adalah tingkat pendidikan orang tua, sosial ekonomi keluarga, tingkat prestasi matematika, sikap matematika, motivasi, jumlah dan kualitas pembelajaran, serta lingkungan kelas yang mendukung proses pembelajaran [12].

Sebagian besar pembelajaran yang mendukung keyakinan yang kuat dalam meningkatkan self concept peserta didik akan menciptakan perubahan yang besar dalam prestasi akademik yang dperoleh $[5,13]$. Peserta didik dengan self concept yang positif akan dapat meningkatkan motivasi dalam dirinya untuk berusaha keras dalam pembelajaran dengan hasil yang memuaskan.

Pemikiran peserta didik SMP khususnya kelas VII berkembang ketika diberikan konsep pembelajaran tidak dalam bentuk final, sehingga mereka dapat memahaminya dengan cara melengkapi, mengelompokkan, dan mengeksplor kemampuan dengan konsep dasar yang diberikan. Kenyataan yang ada dalam penelitian ini membantah asumsi keenam bahwa ratarata terkoreksi self concept peserta didik yang belajar dengan model pembelajaran inquiry terbimbing lebih tinggi daripada rata-rata terkoreksi self concept peserta didik yang belajar dengan model pembelajaran discovery terbimbing.

Pada kelas discovery terbimbing dapat terlihat bahwa peserta didik merasa lebih yakin dengan kemampuan yang dimilikinya dapat menguasai konsep yang diberikan dan merasa yakin atas kemampuan yang dimilikinya sehingga mereka dapat mengembangkan kemampuan tersebut ke arah yang lebih tinggi jika dibandingkan dengan peserta didik yang belajar dengan model pembelajaran inquiry terbimbing.

Self concept peserta didik dapat dibentuk dengan cara menumbuhkan rasa menghargai kemampuan diri sendiri dan merasa yakin akan keputusan yang akan diambil melalui kegiatan diskusi di kelas. Dengan berdiskusi peserta didik diharapkan mau berusaha mengemukakan pendapat dan saling tukar pikiran sehingga materi yang disajikan dapat dipahami dengan baik. Kendala yang diperoleh dari penelitian ini adalah peserta didik kelas VII SMP belum cukup dewasa dan kurang mampu mencari jawaban atau penyelesaian soal secara detail. Hal yang paling sulit adalah ketika mengonstruksi pengetahuan yang baru dengan menggunakan pengetahuan sebelumnya yang menunjang keberhasilan pembelajaran. 


\section{Kesimpulan}

\subsection{Implikasi}

Hasil penelitian menunjukkan bahwa hasil kemampuan berpikir kritis matematis peserta didik yang belajar dengan menggunakan model pembelajaran discovery terbimbing lebih tinggi daripada peserta didik yang belajar dengan model pembelajaran inquiry terbimbing dan pembelajaran konvensional khusus pada peserta didik SMP kelas VII.

Penelitian yang dilakukan pada ketiga kelompok pembelajaran memberikan hasil berdasarkan perolehan nilai peserta didik dan berdasarkan pengamatan yang dilakukan. Pada kenyataan di lapangan tingkat kedewasaan berpikir kritis matematis cukup menjadi perhatian. Rerata hasil pembelajaran yang diperoleh dapat disimpulkan bahwa model pembelajaran discovery terbimbing memiliki rerata terkoreksi yang lebih tinggi daripada model pembelajaran inquiry terbimbing dan model pembelajaran konvensional.

Hasil penelitian menunjukkan bahwa self concept matematis peserta didik yang belajar dengan model pembelajaran discovery terbimbing lebih tinggi daripada peserta didik yang belajar dengan model pembelajaran inquiry terbimbing dan pembelajaran konvensional khususnya pada peserta didik SMP kelas VII.

\subsection{Saran}

Para guru diharapkan dapat menjadi fasilitator dan bukan salah satu sumber belajar agar pelaksanaan pembelajaran berjalan lancar sehingga hasil pembelajaran yang diharapkan dapat tercapai dengan baik serta dapat mengembangkan model pembelajaran matematika yang digunakan dengan menyesuaikan model pembelajaran tersebut dengan materi yang diajarkan.

Kepala sekolah diharapkan dapat memberikan kesempatan kepada guru untuk meningkatkan kompetensinya melalui seminar, workshop dan pelatihan-pelatihan lainnya serta menyiapkan sarana dan prasarana menunjang pelaksanaan pengembangan kompetensi guru. Penelitian ini tidak luput dari keterbatasan, untuk itu diharapkan peneliti lain utuk mengungkap permasalahan yang terkait dengan model pembelajaran berbasis penemuan dalam pengaruhnya terhadap aspek kognitif yaitu kemampuan berpikir kritis matematis dan aspek afektif yaitu self concept matematis di luar materi pelajaran bangun datar.

\section{UCAPAN TERIMA KASIH}

1. Bapak Prof. Dr. Suyono, M.Si, selaku Dekan FMIPA UNJ dan selaku pembimbing I

2. Bapak Dr. Anton Noornia, M.Pd, selaku Koordinator Program Studi Pendidikan Matematika UNJ

3. Ibu Dr. Lukita Ambarwati, M.Si, selaku Pembimbing Akademik.

4. Ibu Dr. Wardhani Rahayu, M.Si, selaku Pembimbing II

5. Ibu Hj. Nurul Huda, M.Si, selaku Kepala Sekolah SMP Negeri 89 Jakarta yang telah memberikan ijin dan dukungan moril sehingga penulis dapat menyelesaikan tesis ini.

6. Ibu Siti Rahmani, S.Pd, selaku Guru Matematika SMP Negeri 89 yang telah memberikan dukungan moril sehingga penulis dapat menyusun tesis ini.

7. Teman-teman seperjuangan angkatan 2015/2016.

8. Ibuku dan suamiku tercinta dan seluruh keluarga.

9. Para dosen dan berbagai pihak yang tidak dapat disebutkan satu persatu atas segala saran dan dukungannya dalam penyusunan tesis ini.

\section{DAFTAR PUSTAKA}


Pengaruh Model Pembelajaran Berbasis Penemuan terhadap Kemampuan Berpikir Kritis Matematis dan Self Concept dengan Mengontrol Kemampuan Awal Peserta Didik Kelas VII SMP pada Materi Bangun Datar

[1] Nizam, 2016. Ringkasan Hasil-hasil Asesmen : Belajar dari hasil UN, PISA, TIMSS, INAP. Puspendik, Balitbang Kemendikbud.

[2] Ennis, 2011. The Nature of Critical thinking : An Outline of Critical Thinking Dispositions and Abilities.

[3] Aizikovitsh-Udi, E., \& Cheng, D.(2015). Developing Critical Thinking Skills from Dispositions to Abilities: Mathematics Education from Early Childhood to High School. Creative Education,6,455-462. http://dx.doi.org/10.4236/ce.2015.64045. (diakses 18 Desember, 2016, pukul 07.47)

[4] Santrock, 2010. A Topical Approach to life-span Development. The McGraw-Hill Companies, Inc. All right reserved

[5] Ayodele, O.J. 2011. Self Concept and Performance of Secondary School Students in Mathematics. Journal of Educational and Developmental Psychology, 1(1). 176-183

[6] Yama dkk, 2015. Perbandingan Model Pembelajaran Guided Inquiry dengan Guided Discovery terhadap Hasil Belajar Siswa. Jurnal Pendidikan Biologi, FKIP Universitas Lampung.

[7] Hermawan, E \& Sondang s, Meini , 2013. Perbedaan Hasil Belajar Menggunakan Model Guded Discovery dengan model Inquiry Pada Pelajaran Memahami sifat Dasar Sinyal Audio di SMK N 2 Surabaya. Jurnal Pendidikan Teknik Elektro, volume 1 nomor 1 (diakses 5 Januari 2017, pukul 21.33).

[8] Meta, dkk. (2014). Keefektifan Model Giuded Discovery dan Guided Inquiry terhadap Keterampilan Proses Sains dan hasil Belajar. Jurnal Pendidikan Matematika dan Sains. FMIPA Universitas Negeri Yogyakarta. (diakses 5 Januari 2017, pukul 21.42)

[9] Putrie,dkk, 2014. Perbandingan Model Guided Discovery Learning dengan Giuded Inquiry terhadap Hasil Belajar Siswa. Jurnal Pendidikan Biologi FKIP Universitas Lampung (diakses 24 Februari 2017, pukul 16.06).

[10] Susilawati, Sri dan Hidayat, Rifqi. 2016. Penerapan Model Pembelajaran Scientific untuk Meningkatkan Kemampuan berpikir Kritis Matematis dan Self Concept Siswa Mts. Pythagoras, 5(1) : 59-65. ISSN 2301-5314. (diakses 18 Desember 2016, pukul 08.22)

[11] Gerlach, Vernon S. \& Donald P. Ely. Teaching \& Media: A Systematic Approach. Second edition. (Englewood Cliffs, New Jersey: Prentice Hall, Inc., 1980)

[12] Erdogan, Fatma., \& Sengul, sare.(2014). A Study on the Elementary School Students" Mathematics Self Concept. Procedia social an Behavioral Sciences 152 (2014) 596601. (diakses 18 Desember 2016, pukul 08.15).

[13] Wang, Jianjun. 2007. A Trend Study of Self Concept and Mathematics Achievement in a Cross-Cultural Context. Mathematics Education Research Journal. Vol 19. No.3.3347. 